\title{
Grundtvig and Tolkien on Beowulf: A comparative analysis
}

\author{
By M. B. Busbee
}

In 1941 Kemp Malone referred to J. R. R. Tolkien's now-famous lecture "Beowulf: The Monsters and the Critics" as "Grundtvig brought up to date". Malone's remark found a respondent in Andreas Haarder, who concluded in 1975 that "Tolkien's conclusions were his own". In lieu of the proliferation of recent studies of the work of Grundtvig and Tolkien, many of which casually assume Grundtvig's influence on Tolkien, it is time to revisit the issues involved in Malone's claim and Haarder's rebuttal. Towards that end, this essay offers an analysis of Tolkien's drafts for his lecture and a comparison of Tolkien's printed lecture and Grundtvig's critical commentaries on the poem between 1815 and 1820 to reconsider the following basic questions: What did Tolkien know about Grundtvig and his criticism? What exactly are the similarities in the Beowulf criticism of the two men? And most importantly, was Tolkien drawing upon or responding to Grundtvig when forming his own ideas about Beowulf?

\section{J. R. R. Tolkien's British Academy lecture of 1936 titled "Beowulf:} The Monsters and the Critics" is widely considered by scholars to be the first effort at interpreting Beowulf on its own terms, as a poem. ${ }^{1}$ The lecture has come to affect study of the poem so deeply that scholars declare that "Beowulf criticism did not begin until 1936" (Fry 1986, ix) and that it is "the single most important critical essay ever written about Beowulf' (Drout 2002, 1). ${ }^{2}$ Hyperbole like this inspires analysis. Tolkien's lecture certainly reinvigorated study of Beowulf; the approach Tolkien modelled seemed fresh and the ideas he presented were eloquently articulated. But was the lecture all that original? Had no one before Tolkien attempted to view the poem on its

The following comment by R. D. Fulk (1991, xi-xii) is representative of this scholarly consensus: "No one denies the historical importance of [Tolkien's] lecture as the first sustained effort at viewing the poem on its own terms, according to aesthetic guidelines discoverable in the work itself, thus opening the way to the formalist principles that played such a vital role in the subsequent development of Beowulf scholarship."

2 Other high-profile Beowulf scholars concur: John D. Niles considers Tolkien's lecture to have ushered Beowulf "fully into the ranks of English Literature" (1983, 4); George Clark calls it "a turning point in the history of Beowulf in the modern age" (1990, 7-8); and E. G. Stanley writes that Tolkien's essay marked "the beginning of a new age" for the poem (1994, 37 38). 
own terms? In a 1939 review of the lecture, American medievalist Howard Patch complained that Tolkien "is more indebted to the philologists, mythologists, and archaeologists" than he lets on (Patch 1939, 217). And in 1941, American Anglo-Saxonist Kemp Malone implied that Tolkien's ideas might not be anything new. In his essay "Grundtvig as Beowulf Critic," Malone introduced his topic and quickly turned to the question of Tolkien's originality. ${ }^{3} \mathrm{He}$ wrote:

The first and greatest of Beowulf scholars, as everybody knows, was N. F. S. Grundtvig. (...) Of the many scholars who have followed Grundtvig in the field, none can compare with him in genius or in importance of achievement. (...) As a literary critic, however, he has received little attention. His views were ignored by most of his contemporaries, who preferred mythology and literary dissection, and in later times Beowulfian literary scholarship seems not merely to ignore but to be ignorant of his critical writings. Thus, Professor Tolkien, in his recent British Academy lecture, passes Grundtvig over in silence, although the problem which he discusses, and the conclusions which he reaches, may not unfairly be described as Grundtvig brought up to date. It seems evident that Tolkien's work is independent and original, and one must conclude that he was not familiar with Grundtvig's critical writings (Malone 1941, 129-130).

Malone does not explain what he means by "the problem" that Tolkien discusses and "the conclusions" he reaches or how they resemble the ones Grundtvig discussed and reached more than one hundred years earlier. He does, however, provide two reasons why Tolkien was likely unfamiliar with the ideas of his Danish predecessor: Grundtvig wrote in Danish, which Malone believed Tolkien could not read, and Grundtvig's "critical writings are buried in out-of-the-way publications" and were therefore inaccessible to present-day scholars, such as Tolkien (Malone 1941, 130). These points seem to have been made in the vein of gentle teasing and good-humoured scholarly oneupmanship. It is clear, however, that after reading Tolkien's lecture, Malone was struck by the similarity of Tolkien's and Grundtvig's points about the monsters' centrality to the poem's theme, which he goes on to discuss in his article. It could be that other characteristics that they shared attracted his attention: Tolkien's willingness to speak about Beowulf in richly allusive language and to locate messages in it about the fate of man, the cosmic battle between good and evil, and the

3 In this article, Malone mentions the following pieces of Grundtvig's criticism on Beowulf: "Om Bjovulfs Drape" in Danne-Virke II (Grundtvig 1817, 207-289); Bjowulfs Drape (Grundtvig 1820, Introduction, xxiii-lxxiv); "Bjovulfs Drape" in Brage og Idun IV (Grundtvig 1841, 481-538); and Beowulfes Beorh (Grundtvig 861, Introduction, xv-lvii). 
patterns of history - all of which were at some point parts of Grundtvig's thinking about Beowulf.

In Beowulf: The Appeal of the Poem, Andreas Haarder $(1975,64)$ staged a response to Malone, insisting that "Tolkien's conclusions are his own. Even with modifications Grundtvig will not fit into the framework proposed by Malone". ${ }^{4}$ In recent years, with the advent of Tolkien Studies in English departments in America and Great Britain, the proliferation of scholarly articles and books devoted to Tolkien and the sources for his writings, and the promulgation of films and other media adapted from Tolkien's oeuvre, the suggestion raised by Malone has quietly resurfaced. For example, Nils Ivar Agøy (1996, 35), a Norwegian translator and scholar of Tolkien's work, writes in passing: "What Grundtvig had to say about Beowulf was in fact very similar to what Tolkien stated in his lecture". Tom Shippey and Michael Drout, Beowulf scholars who also study Tolkien, confidently claim (also in passing) that "Grundtvig was the 'Beowulfian' whom Tolkien admired most" (Shippey 2003, 347), and that "the great synthesizing works" of Grundtvig in his original Danish were "well known to Tolkien" (Drout 2004, 238).

Statements like these signal that it is time to revisit the possibilities that Tolkien did actually know about Grundtvig and his critical work on Beowulf, that the two men were similar in their criticism of the poem, and finally, that Tolkien might have been directly drawing upon or responding to Grundtvig's ideas when composing his famous lecture of 1936. In this essay I explore these possibilities by considering Tolkien's own notes about Grundtvig and by analysing and comparing his delivered lecture of 1936 and drafts of it to select portions of Grundtvig's remarks about Beowulf between 1815 and 1820. These documents contain many striking similarities ranging from surface points, such as how the two scholars described the poem and its provenance, to more profound deliberations, such as how they regarded the poem as an expression of truth, generated at a providential moment in history, and how they interpret the monsters in Beowulf.

What did Tolkien know, if anything, about Grundtvig's writings on Beowulf? Drafts for his 1936 lecture reveal that Tolkien not only knew about Grundtvig, but that he was also aware of the broad range of his criticism and that he very likely read parts of it. The manuscript, containing two separate drafts referred to as drafts " $A$ " and "B", was donated to the Bodleian Library Oxford in 1985 and was published by

4 Many of Haarder's points about the differences between Grundtvig's and Tolkien's Beowulf criticism first appeared in "Grundtvigs vurdering af Beowulf som kunstværk" (1965, 7-36), which was published in this journal. 
Michael Drout in 2002 as an edition titled Beowulf and the Critics, after Tolkien's collective title for the drafts. ${ }^{5}$ Of crucial practical importance to a comparative study is the fact that in drafts " $\mathrm{A}$ " and "B" Tolkien devotes a paragraph to "Pastor Grundtvig", calling him "one of the greatest single names in the history of Beowulf-criticism" and representative of "the first stage of Beowulf criticism" (Tolkien 2002, 43). He appends the following remarks about Grundtvig in a lengthy footnote, which I have reproduced in full:

I have not time here to say much about [Grundtvig]. With practically no material for study he tackled the elucidation of Old English verse language brilliantly, and made such advances that his own AngloSaxon verse in commendation of [Johan] Bülow, though it will not now pass muster except where it is mere quotation is nonetheless recognizably "like" in metré [sic] and idiom. His "emendations" of Thorkelin's faulty text were often found actually to be in the Mss (which he had not seen when he made them) - a thing which seemed almost like sorcery to those unable yet to swallow the notion that other languages than Latin, Greek and Hebrew had any shape or rules. This ensured him nonetheless a hospitable welcome in England and Oxford; and served to reawaken a belief that there might be something in this Anglo-Saxon stuff after all. A large part of Oxford remains, however, as secure in its ignorance of the field and the achievements of AngloSaxon scholarship as it was when it shook its head in half incredulous wonder over N. F. S. Grundtvig, Prcest. Among examples of Grundtvig's sagacity one may mention that it was he who first made out many of the proper names in the text, first discerning Sigemund the Volsung for instance; and it was he who first identified Hygelac with the Chochilaicus in Gregory of Tours, a discovery of cardinal importance. It was Grundtvig who published the first translation of Beowulf into any modern language: Bjowulfs Drape. Et Gothisk HelteDigt fra forrige Aar-Tusinde af Angel-Saxisk paa Danske Riim ved Nik. Fred. Sev. Grundtvig, Proest. Kjöbenhavn, 1820.

Parts of this note seem to have been paraphrased from the introduction to John Earle's Deeds of Beowulf, which may have led Tolkien to

5 When Christopher Tolkien donated the manuscript to the Bodleian Library, he made the following remarks about the drafts: "I do not know whether Beowulf and the Critics was composed with the British Academy lecture already in mind, or whether when the occasion arose to give such a lecture my father decided to draw on and reduce Beowulf and the Critics already in existence for another purpose" (quoted in Drout 2002, xv). This remark raises the possibility that Tolkien had been familiar with Grundtvig's criticism long before 1936. 
Grundtvig's chief editorial and critical commentaries on Beowulf. ${ }^{6}$ Earle would not have been Tolkien's only source: Grundtvig was commonly referred to in standard works on Beowulf produced by other high-profile Beowulf scholars who were contemporaries of Tolkien. For example, in his 1925 edition of Beowulf, which has since become the standard, Fr. Klaeber demonstrates intimate knowledge of the details of Grundtvig's critical and textual works by footnoting them some 155 times in his edition. ${ }^{7}$ And R. W. Chambers, another highly respected Beowulf scholar and friend of Tolkien, also took special notice of Grundtvig's influence on English scholarship. He notes that the "bold project of a foreigner [Grundtvig] shamed Englishmen into action" (1932, iii). ${ }^{8}$ Most influential of any of his sources, however, would certainly have been Earle's text. John Earle was one of Tolkien's predecessors as Rawlinson Professor of Anglo-Saxon at Oxford, and he was a friend and admirer of Grundtvig. As his letters to Grundtvig attest, Earle studied Grundtvig's writings, especially his Beowulf translation and his book on mythology, Nordens Mythologi (1832), and he acted as a sort of go-between for English scholars of Beowulf and the Danish priest. ${ }^{9}$ In his ninety-page introduction, Earle devotes five pages to outlining Grundtvig's contributions, including his 1815 discussions of the poem in "Et Par Ord om det nys udkomne angelsaxiske Digt" (A Few Words about the newly published AngloSaxon Poem) and "Nok et Par Ord om Bjovulfs Drape" (Another Few Words about Beowulf) and his 1820 translation Bjowulfs Drape.

Tolkien certainly had Grundtvig and his 1820 translation firmly in mind as he proceeded with his second draft for the lecture. In draft "B" Tolkien reproduces verbatim his footnoted remarks about Grundtvig,

6 Michael Drout $(2002,6)$ suggests that Earle was a chief source for Tolkien's drafts. A few sentences in Tolkien's comments appear to have been paraphrased from Earle's "Introduction" (1892, ix-c).

My count includes Klaeber's references to Grundtvig's editorial commentaries on the text of Beowulf over the course of nearly fifty years. Klaeber refers mostly to Grundtvig's 1820 translation and his 1861 edition.

8 Many other medievalists that Tolkien knew and admired also took notice of Grundtvig's Beowulf scholarship. One prominent example is Jacob Grimm $(1823 / 1869,180-81)$ who reviewed Grundtvig's translation of Beowulf, praising it for its importance to future scholarship.

Earle's letter exchanges are archived in Fasc. 448. 10 a-e in the Grundtvig Archive in the Royal Library of Denmark. In Fasc. 448.10 a (dated 11 April 1848), he tells Grundtvig that he is planning to translate Nordens Mythologi. Nothing appears to have come of those plans. In Fasc. $448.10 \mathrm{~b}$. (30 March, 1849), he writes, "I have read some of your translation of the Beowulf. Kemble speaks very highly of it: he says, it is the only one that is good." 
but he moves them from the footnotes to the main body of the text and adds a stanza from the dedicatory poem to Johan Bülow in Bjowulfs Drape to demonstrate the Dane's sophisticated handling of Old English verse. ${ }^{10}$ This latter addition, written in pencil in the margins, solidifies the possibility that while in the process of developing ideas for the lecture, Tolkien had (re)read Grundtvig's 1820 translation or at least the introductory material where Grundtvig laid out his criticism of the poem.

For reasons unknown Tolkien cut paragraphs about Grundtvig's scholarship from the delivered and printed versions of his lecture. Maybe he removed them for brevity's sake; maybe he determined that his audience need not be burdened with superfluous commentary on Grundtvig's achievements. Tom Shippey suggests that Tolkien was not in the habit of citing his sources, but that Grundtvig is referred to in the lecture, though relegated to anonymity: "He appears," Shippey writes, "(...) as one of the "very old voices' calling "it is a mythical allegory (...) generally shouted down, but not so far out as some of the newer cries" " $(2003,343,347) .{ }^{11}$

How "far out" Tolkien considered Grundtvig's ideas to be depends upon how well he understood them. The depth of his understanding depends in turn upon the practical question of how well he could read Grundtvig's Danish and thereby access his views directly. It has been noted that what we know of Tolkien's library and his scholarly habits suggests that he was not comfortable in Scandinavian languages. Of

10 The passage is from Bjowulfs Drape, unnumbered, XVII-XVIII. I have preserved Tolkien's formatting of the passage, which differs from Grundtvig's life-long practice of presenting Old English verse by half-line.

$\begin{array}{ll}\text { Freodoric sitep } & \text { On fæder-stole } \\ \text { Gumena baldor } & \text { Pæt is god cyning. } \\ \text { Swylcum gifepe bip } & \text { Pæt he Grendles cynn } \\ \text { Denum to dreame } & \text { Dæda getwæfe } \\ \text { A pone sinc-gyfan } & \text { Ymbe-scinon } \\ \text { Witena betstan } & \text { Wis-fæste eorlas } \\ \text { Monige swylce } & \text { On Middan-gearde } \\ \text { Swylc Bilof is } & \text { Byre æpelinga. }\end{array}$

Tolkien's translation of this passage is as follows: Frederik sits on the fatherseat, the master of men. That is a good king. It is given to him that he should deprive the race of Grendel of their deeds, to the delight of the Danes. Wise earls, the best of councilors, always shone around the treasure-giver, many such on middle-earth, as is Bülow, protector of princes. (Tolkien 2002, 99).

11 Shippey is quoting from Beowulf: The Monsters and the Critics (Tolkien 1958, 5). 
the 320 books Tolkien donated to the Bodleian Library and the English Faculty Library in Oxford, only five are in Scandinavian languages, and a survey of Tolkien's scholarship reveals that he rarely referred to Scandinavian-language academic literature in his own published writings. ${ }^{12}$ These problems seem easily solved if we acknowledge that in his studies at Oxford, Tolkien would have been required to have knowledge of Gothic, Old Norse, Old High German and Old English. He worked on the Oxford English Dictionary and would therefore have encountered and read a variety of modern Germanic languages. In 1927, Tolkien $(1927,33)$ reviewed Otto Jespersen's Danish Menneskehed, Nasjon, og Individ i Sproget, giving it eight sentences of high praise in "Philology: General Works." In the privately published Songs for Philologists (1936) to which Tolkien was a major contributor, there are also pieces written in Danish. And in a 1957 letter to a Swedish translator of the Lord of the Rings, Tolkien (1981, 263) revealed that he could work through a Scandinavian text, aided by a dictionary and a strong personal interest.

Based on the comments in his lecture drafts, Tolkien's strong personal interest in Grundtvig is undeniable. Tolkien found a kindred spirit in Grundtvig, particularly in his effort to inspire "scholars, who had been nurtured upon foreign classics, [to] begin to wonder whether there might not be more in the treasury of their own mother tongue than they had hitherto apprehended" (Earle 1892, xvi). Grundtvig's agenda for Beowulf as an instrument for national and spiritual inspiration may be a crucial reason that Tolkien took special note of Grundtvig. Beyond all of his achievements as a scholar, most important is that

Grundtvig did for Denmark what Tolkien would have liked to do for England: he gave it a history and a mythology founded on ancient sources, but released again into national life and national politics by his popular writings [and] his many songs and hymns (Shippey 2004, $1-15)$.

Both men acknowledge the potential for works like Beowulf to inspire national pride, though it seems that Grundtvig employed its potential consciously and Tolkien unconsciously. This shared attitude may have been on Malone's mind when he first proposed that "Tolkien's lecture was simply Grundtvig brought up to date" (1941, 130). In his 1975 response, Andreas Haarder claimed that Grundtvig and Tolkien addressed different problems and reached different conclusions in their thinking about the poem. Haarder seems correct in asserting that

\footnotetext{
12 Agøy $(1995,36)$ raises questions about the quality of Tolkien's reading ability in Danish.
} 
Grundtvig's mythical interpretation was the major point of difference, one which in the end left him unable "to identify an evaluation of the work of art as a whole" $(1975,78)$. In Haarder's thinking, Tolkien was not hampered by such a personal agenda; instead, his "structural interpretation" allowed him to "vindicate it as a work of art with monster fights and digressions as valuable parts of well-integrated whole" (Haarder 1975, 149). By locating this central difference between the two scholars' approach, Haarder was able to conclude that with Grundtvig's criticism "we are not anywhere near the holistic interpretation advanced by Tolkien" $(1975,75)$.

I would argue rather that Haarder's distinction inadvertently presents a starting point for identifying fundamental similarities in how Tolkien and Grundtvig interpret Beowulf. The ideologies that compelled them to locate meaning in Beowulf.were quite similar, but the ends to which they put the poem were different. In both cases the effort involved reconciliation of the message of the poem to their nationalism and Christianity. How Grundtvig applied his so-called "mythical interpretation" of medieval texts in his writings between 1815 and 1820 as a part of an ideological program that he was advancing is well documented. ${ }^{13}$ Until recently, few have acknowledged what Jane Chance (2001) has called Tolkien's "mythology for England." Early evidence of this appears in The Hobbit, which he began in $1928 .{ }^{14}$ When asked about the source for the book, Tolkien replied, in a letter published in the Observer on 20 February 1938, that he derived it from "epic, mythology, and fairystory", and he specifically acknowledged that Beowulf was his "most valued" source, "though it was not consciously present to the mind in the process of writing" $(1938,9)$.

Could it be that Grundtvig's conscious effort to construe Beowulf according to his philosophy had become an attractive model for Tolkien when he was crafting his lecture? In his lecture notes, Tolkien displays sensitivity to Grundtvig's attitudes about ancient texts and their explication, namely the emphasis on Germanic rather than Classical philology and his effort to "awaken" interest in Anglo-Saxon literature. In 1941 Tolkien wrote the following in a letter to his son:

13 For a discussions of Grundtvig's uses for mythology, see LundgreenNielsen's "Grundtvig's Norse Mythological Imagery - an Experiment That Failed" (1994, 41-67) and Lars Lönnroth's "The Academy of Odin: Grundtvig's Political Instrumentalization of Old Norse Mythology" (1988, 338-354).

14 Chance $(2001,2)$ writes that Tolkien's "own developing mythology of Middle-earth reshap[ed] his responses to medieval literature". 
I have spent most of my life, since I was your age, studying Germanic matters (in the general sense that includes England and Scandinavia). There is a great deal more force (and truth) than ignorant people imagine in the "Germanic" ideal. I was much attracted by it as an undergraduate (when Hitler was, I suppose, dabbling in paint, and had not heard of it), in reaction against the "Classics" (Tolkien 1981, 54$55)$.

Also revealing are his comments in 1951:

once upon a time (...) I had a mind to make a body of more or less connected legend, ranging from the large and cosmogonic, to the level of the romantic fairy-story $(, \ldots)$ I would draw some of the great tales in fullness, and leave many only placed in the scheme, and sketched. The cycles should be linked to a majestic whole, and yet leave scope for other minds and hands, wielding paint and music and drama (Tolkien 1981, 144-145).

These remarks pertain chiefly to Tolkien's creative works, namely The Hobbit and The Lord of the Rings trilogy. But they reveal an overarching literary sensibility that applies to Tolkien's ideas about Beowulf.

The efforts of both men, whether conscious - Grundtvig's interpretation - or unconscious - Tolkien's - are focused on finding unity and reconciliation for the ancient traditions found in Old English literature. Tom Shippey argues that both men engage in reconciling the pre-Christian literature with their own patriotic and Christian beliefs; however, differences in perspective - Grundtvig was an evangelical Protestant and Tolkien was a devout Catholic - caused them different problems and led them in different directions. In keeping with his idiosyncratic ideas on world history, Grundtvig's solution was to interpret Beowulf as embodying evidence of the revelation of "The Truth", which he associated with divine providence. Less compelled by the need to find a spiritual message in Beowulf, Tolkien approached the problem of how to reconcile the old poem and the world-view expressed in it to a modern audience from a literary perspective, one newly fashionable in the early part of the twentieth century. ${ }^{15}$

If we read drafts " $A$ " and " $B$ " of the lecture alongside the final delivered version, we can observe Tolkien's literary temperament for Beowulf. begin to evolve from a religious and patriotic temperament like Grundtvig's. We can see him groping for a literary theme - or

15 Shippey (1997, 14-16) articulates this different approach as follows: "[Tolkien] seems to me to have turned the problem of reconciliation from one of belief to one of literary temper: from considering the Echtheit or 'genuineness' of the faith of his heathen ancestors to considering its literary attraction." 
writing himself to clarity - over time, while clinging to a few guiding principles, ones similar to Grundtvig's on their surface but eventually working towards a different end. From drafts to final lecture, Tolkien's principal theme changed from a survey of the ideas of the most important Beowulf scholars, including Grundtvig, to an argument that the monsters are central to the structure and meaning of the poem. We will return to that central argument later. For now, it is useful to gain a broader view of what the two scholars had to say about Beowulf. A starting point is identifying the three following foundational concepts in Tolkien's drafts and final lecture:

1) Beowulf was composed at a "time of fusion" in history (Tolkien 1958, 18), the world was rapidly changing.

2) The poem "glimpses the cosmic" and concerns "the fate of human life and efforts" and therefore has a providential message of enduring kinship to a modern audience (Tolkien 1958, 33).

3) As a vehicle for the second point, the monsters in Beowulf symbolise the "powers of darkness" with which man has to contend "on the fields of time" (Tolkien 1958, 20).

Like most of his contemporaries, Tolkien $(1958,18)$ accepts "without argument throughout the attribution of Beowulf to the 'age of Bede'," that is, the early part of the eighth century. He writes that it was composed by a poet "whose grandchildren were at grips with such Teutons par excellence, the Viking invaders, and regarded them as the very devil" $(2002,38)$. He believes that the poem was therefore composed in a providential "time of fusion", "a pregnant moment of poise" when "the great pagan [stood] on the threshold of the change of the world" (Tolkien 1958, 22-23). This poet was "a learned man writing of old times, who looking back on the heroism and sorrow feels in them something permanent and something symbolical" (1958, 25). And those permanent symbols elevate the poem to the status of "myth incarnate" $(2002,145)$; Beowulf is like an "echo of an ancient dirge (...) to us as a memory brought over the hills, an echo of an echo" $(2002,53)$. It is not an epic but "something else altogether" $(2002,107)$. "Though if we must have a term," Tolkien writes, "we should choose rather "elegy'." Beowulf is a "heroic-elegiac poem" that contains a message that can profit the soul $(1958,31)$.

Note the similarity of Tolkien's comments with Grnndtvig's, about when and why Beowulf was written and what sort of poem it is. 
Concerning its provenance, Grundtvig contends that the poem was written "mens man havde godt Greb paa Harpen og godt Øie til de Danske, altsaa vist førend det ottende Aarhundrede var kommet vidt", (when the harp was still in use and the Danes were still in favour; doubtless, that is to say, before the eighth century was far advanced, 1817, 288). Like Tolkien, Grundtvig considers the poem to be the product of a special moment in history. He calls Beowulf the first attempt in Christendom to raise secular history to an epic. ${ }^{16}$ The poem "er Aandens Stemme" (is the voice of the spirit, 1832, 194-195); it strives to express "Ordets Kamp til Seier" (the Word's fight to victory, $1817,274)$. In the introduction to his 1861 edition, Grundtvig writes that Beowulf has "verdens-historisk (...) Betydning og Vigtighed" (world-historic (...) meaning and importance, 1861, xxxiv). Like Tolkien, Grundtvig hesitates to call Beowulf an epic. It is "episk Syn, men intet Epos" (an epic vision, but no epic, 1817, 277).

The language both men use when discussing the provenance and nature of Beowulf reveals that they both want to (re)establish the poem's spiritual and national significance. ${ }^{17}$ Seth Lerer $(1997,329)$ claims that Tolkien mainly wanted to "save the literary integrity of the poem from the hands of dismembering historians". Certainly Tolkien's notion of what needs to be saved runs much deeper, when he claims, for example, that Beowulf is an "echo of an ancient dirge [which is] to us as a memory brought over the hills" $(2002,53)$. He repeats this analogy in the final lecture, writing: "If the funeral of Beowulf moved once like the echo of an ancient dirge, far-off and hopeless, it is to us as a memory brought over the hills, an echo of an echo" $(1958,34)$. Imagery that Grundtvig employs is strikingly similar. For example, he often titled his remakes of ancient Scandinavian poems "efterklange" (echoes), because he believed they carried messages that might resonate with modern audiences. ${ }^{18}$ The goal of the "Efter-Klang" is to recreate a particularly national feeling, one that modern Danes can share with their ancient ancestors. ${ }^{19}$ In 1817 he brought Beowulf in line

16 In 1830, Grundtvig claims that the poem is "the earliest attempt, in any vernacular dialect of modem Europe, to produce an epic poem" $(1830,8)$.

17 Seth Lerer $(1997,329)$ categorises Tolkien's language about Beowulf, "rhetoric of salvation", which seems, in my thinking, also to suit Grundtvig's language.

18 Anders Holm's Historie og efterklang - en studie i N. F. S. Grundtvigs tidsskrift Danne-Virke (Odense 2001) provides a useful explanation of Grundtvig's preoccupation with his theory of history between 1816 and 1819 .

19 Grundtvig uses the word "Efterklang" in the titles of five poems appearing in 1816 and 1817, when he was working on Beowulf. The first of these serves as an example of Grundtvig's uses of medieval themes. The poem appeared in Heimdall on 28 December 1815 and is titled merely "Efter- 
with his idea of "efterklange", calling the poem "en Guldharpe fra Hedenold, hvis Strænge sprang, og hvis Skruer smeltede i Luen" (a golden harp from heathen times, whose strings burst and whose pegs melted in the blaze; 1817, 271). Like an ancient harp in the hands of a capable craftsman (perhaps Grundtvig himself), Beowulf might be not only saved, but refashioned and renewed so that across the void of time it might be heard, understood and appreciated by a modern audience.

A likely result of his efforts to renew and refashion what he found in Beowulf was that Grundtvig felt frustrated with the poem and therefore unable to call it an artistic whole. But close study of Tolkien's drafts and lecture reveal that he has his own nagging reservations about the artistry of Beowulf In draft " $A$ " of the lecture, Tolkien similarly regrets (in language similar to Grundtvig's) that

the interweaving by speech and allusion of past events (...) is not wholly successful. The surface is too broken; reminiscence is too long in proportion and not always sufficiently suitable in the character and atmosphere of the things told and recalled to the general theme of Beowulf's fall (Tolkien 2002, 76).

In draft " $\mathrm{B}$ " Tolkien repeats this complaint and begins to work his way to the idea that Beowulf has a "static contrast-structure" $(2002,140)$, thereby arriving at a unique idea that the poem must be taken as an whole in order to redeem what might otherwise seem to be flaws. In the lecture, he softens his critique, stating only that Beowulf's "recapitulation" of events in Denmark "is well done", but not well enough to "justify the repetition" $(1958,28)$. Some scholars have seen Tolkien's insistence that the poem is a balance of beginnings and endings, youth and old age as an effort to reconcile problems in the poem's narrative (Clark 1997, 280). Like Grundtvig, Tolkien searches for ways around the problems he found with the poem's artistry. His final critique finds that the monsters provide the poem with unity; Grundtvig's does not. For Tolkien, Beowulf is a literary artifact from a distant time, a monument to a past age that still has meaning for modern readers. For Grundtvig, it is a living expression of the struggle that mankind faces at all times in history.

The third and most important idea that Grundtvig and Tolkien share about the poem is that the monsters symbolise forces of evil, with which man must struggle. Out of this theme emerges the clearest indication that Tolkien was somehow borrowing from or responding to

klang". Grundtvig transfers the characters from myth and legend into another medium and, as a result, enlarges or enhances their significance for modern times. 
Grundtvig. We know that at some point between drafts "A" and "B" Tolkien consulted Grundtvig's translation, Bjowulfs Drape, in order to add an exemplar of Grundtvig's creative use of Old English verse. When he did, he likely encountered in Grundtvig's introduction the following remarks about the poem's nature and how the monsters contribute to the poem's meaning:

Jeg finder nemlig at Bjowulf er med et dybt poetisk Blik betragtet og levende fremstilt som Menneske-Slagtens Nordiske Helt, der, tilsidst paa sit eget Livs Bekostning, afvæbner Mørkets Magt og redder med Kraft det døende Folke-Liv, og har jeg Ret, da er Digtet ogsaa unægtelig høit, ja en Thors-Drape, hvortil selv ei Island kan opvise Mage.

Jeg finder end videre, at Bjowulfs eventyrlige Kampe betegner de to store Afdelinger af Menneske-Kampen mod hin Mørkets Magt, som deels yttrer sig i voldsomt Anfald paa Kæmpe-Livet, deels i Rugen over de Vaaben og Skatte som høre til dets Fortsættelse, eller med andre Ord; deels i Historien og deels i Naturen. (...) Min tredie Udsættelse er den, at Episoderne ere for det meste smagløs, og tildeels i Billinger indskudte, hvorved Digtet taber sin Runding og en Deel af sin Klarhed, saa min Daddel er neppe ugrundet (Grundtvig 1820, LLI).

(I find indeed that Bjowulf is considered with a deeply poetic eye, and vitally portrayed as the Nordic hero of the race of mankind, who, finally, at the cost of his own life, disarms the powers of the dark and rescues by his strength the dying life of the people; and if I am right, then the poem is also beyond question elevated; it is England's ThorsDrape, of which not even Iceland itself can show the like.

I find furthermore that Bjowulf's adventurous fights symbolise the two great divisions of the fights of humanity against the power of the dark, which expresses itself partly in violent assault on the heroic life, partly in brooding over the weapons and treasures which belong to its continuation, or in other words: partly in history and partly in nature. (...) My third point of criticism is this, that the episodes are for the most part tastelessly inserted and partly in fragments, as a result of which the poem loses its form and part of its clarity, so my censure is hardly without basis). ${ }^{20}$

20 By 1817 Grundtvig had already issued these remarks about the tastelessness of the English and by association Beowulf: "Kort sagt, man sporer her, som hos Shakspear, og vel i al engelsk Poesie, en Bestræbelse efter planmæssig at frembringe colossale Konst-Værker, som aldrig kan lykkes uden, hvad Angler og Engellænder altid have savnet, det er: Smag" (In short, one traces here, as in Shakespeare, and I suppose in all English poetry in general, a striving to produce colossal works of art according to plan, something that will never work without the quality which has always been 
It is not difficult to imagine Tolkien pausing to consider passages like this one and, being drawn to the possibilities and challenges Grundtvig raises, deciding to shift the focus (and his title) of his lecture from "Beowulf and the Critics" to "Beowulf: the Monsters and the Critics." In his drafts the monsters do not figure in his thesis. Instead, he is "concerned with (...) that relatively small department of Beowulf bibliography" which discusses Beowulf "as a poem, as a work of art, showing structure and motive" (Tolkien 2002, 80). The final lecture places these ideas at its centre, and the thesis changes tellingly in the following statement:

I shall confine myself mainly to the monsters - Grendel and the Dragon, as they appear in what seems to be the best and most authoritative general criticism in English - and to certain considerations of the structure and conduct of the poem that arise from this theme (Tolkien 1958, 2).

Midway through the lecture, as though responding directly to Grundtvig's remarks about how the poet tastelessly inserted episodes, Tolkien asserts that

the monsters are not an inexplicable blunder of taste; they are essential, fundamentally allied to the underlying ideas of the poem, which give it its lofty tone and high seriousness (Tolkien 1958, 17).

Once again using language that engages Grundtvig's comments in 1820 , Tolkien states that the monsters exist so that "we may see man at war with the hostile world and his inevitable overthrow in time" (Tolkien 1958, 16). The hero meets them in "a contest on the fields of Time", in a "battle between the soul and its adversaries" (1958, 20, 21). And at the end of the lecture, Tolkien states:

It is just because the main foes in Beowulf are inhuman that the story is larger and more significant than this imaginary poem of a great king's hall. It glimpses the cosmic and moves with the thought of all men concerning the fate of human life and efforts $(1958,33)$.

In passages like this one, we can discern surface similarities as well as fundamental differences of perspective. In Grundtvig's thinking "Time" is categorically Christian and providential; all that happens within time happens within divine providence. Tolkien's perspective is conditioned by a post-World War I sense of tragedy (he uses the word nine times in his lecture) and a romantic appreciation of the death of the hero as nobly fated - "the wages of heroism is death" $(1958,25)$. Consequently, the individual monsters, Grendel and the dragon - like 
Grundtvig, Tolkien mostly ignores Grendel's mother in his criticism become for Tolkien the product of a "time of fusion", when a shift was still occurring between Pagan and Christian world-views. The monsters, who had been enemies of the gods, "became inevitably the enemies of the one God" (Tolkien 1958, 20) and, as he explains in draft " $A$ ", also denizens of the physical world, where they torment mankind:

Grendel although a feond on helle (enemy in hell) is primarily a feond mancynnes (enemy of mankind), he and his kin are in this world eaters of the very flesh of men, they are in the physical world and of it because they are indeed $i t$ itself. We are dealing still with the tragedy of man in time. (...) Grendel becomes more 'devilish' and less merely elemental - more like the inner enemy, the evil possibilities of debased human nature (Tolkien 2002, 67, 76; Emphasis is Tolkien's).

In his lecture he expands upon this idea of the dual symbolism, first by referring to a statement by R. W. Chambers: "Grendel and the dragon are constantly referred to in language which is meant to recall the powers of darkness" $(1958,17){ }^{21}$ Then, Tolkien complicates that statement: "Grendel inhabits the visible world and eats the flesh and blood of men; he enters their houses by the doors" $(1958,21)$.

The dragon also has a dual meaning. Tolkien writes that "Beowulf's dragon" is

a personification of malice, greed, destruction (the evil side of heroic life), and of the undiscriminating cruelty of fortune that distinguishes not good or bad (the evil aspect of all life) (...) The dragon wields a physical fire and covets gold, not souls; he is slain with iron in his belly (Tolkien 1958, 15, 21-22).

The sentiments expressed in the above passages also appear in Grundtvig's criticism of the poem. Like Tolkien, Grundtvig considers the monsters to be essential to the poem's interpretation; he proposes that the Christian poet drew upon heathen symbols to give the poem a higher meaning; and he argues that the monsters provide readers with a vision of man's cosmic struggle against forces of darkness. In his most complete statement of the meaning of the monsters, his 1817 essay "Om Bjowulfs Drape", he covers all of these points. Concerning the centrality of the monsters in the mind of the Christian poet, he writes

Naar altsaa Skjalden vilde prøve det Vovespil at samle hedenske Begivenheder til et Epos, uden dog selv at giøre sig til Hedning, saae han ingen anden Udvei, end at tye til Eventyret, og derigiennem sætte

21 Tolkien quotes this line from the foreword by R. W. Chambers to Archibald Strong's 1925 translation of Beowulf (xxvii). 
Begivenhederne i et Slags Forhold til den christelige Sandhed, derfor staae Eventyrene om Grændel og Dragen som Digtets Hoved-Indhold, som en Fortsættelse af Djævelens og de gamle Geganters Kamp imod Gud, der som Trolddom griber ind i Historien, og skal derved give den en høiere Betydning (Grundtvig 1817, 278).

(When the skald wanted to try the gamble of gathering the heathen events into an epic without making a heathen of himself; he saw no other way out than to have recourse to folk-tale matter and thereby to provide the events with a kind of relation to Christian truth; therefore the tales about Grendel and the dragon stand as the main content of the poem, as a continuation of the war of the Devil and the ancient giants against God, which, as the sorcery [entailed in the monsters], affect the course of history, and they are in this way meant to give it a higher meaning).

The monsters represent "to Afsnit i den store Kamp, der kan siges at skygge i det dobbelte Eventyr' (two parts of the great fight, which may be said to shadow forth in the double adventure, 1817, 279). Like Tolkien, Grundtvig sees synthesis of heathen and Christian perspective in the monsters. He explains:

Løgnens fiendtlige Forhold mod Sandheden viser sig nemlig: deels i dens Anfald paa Sandheds Rige, deels i det Dølgsmaal den lægger paa Sandheds lovlige Eiendom, med andre Ord: deels i Historien, og deels i Naturen, og nu kan vi ikke nægte, at Eventyrene, som Skyggeværk svare dertil, da Grændel staaer som Tidens, Dragen som Naturens onde Aand (Grundtvig 1817, 279).

(The antagonism of The Lie to The Truth shows itself partly in The Lie's attack on the realm of Truth, partly in how The Lie conceals the lawful property of Truth, in other words, partly in history, and partly in nature, and now we cannot deny that the tales correspond to this as shadow pictures, in that Grendel functions as the evil spirit of time, the dragon as the evil spirit of nature).

What conclusions can be drawn from these comparisons? From his remarks in the drafts for his lecture, it is clear that Tolkien knew about Grundtvig and his criticism when drafting his 1936 lecture. It seems clear also that he consulted Grundtvig's work while composing it. Comparisons of his remarks on the nature of the poem and its monsters with Grundtvig's suggest that Tolkien quite possibly incorporated many of Grundtvig's ideas into his own thinking about Beowulf. Sometimes he sought to challenge them, sometimes to build upon them. Despite these conclusions, it remains difficult to assert that Tolkien was deeply indebted to Grundtvig for the content of his ground-breaking lecture, "Beowulf: The Monsters and the Critics". 
Rather, I would build upon S. A. J. Bradley's statement about Grundtvig's enduring influence through Tolkien:

Since it is roughly true to say that Beowulf literary scholarship since Tolkien's paper has largely followed Tolkien's lead, it could be said, with Malone, that Grundtvig, in a sense a century ahead of his time, has at last come into his own (Bradley 1990,216).

The engagement Tolkien had with the ideas of his Danish predecessor was no doubt mediated by the long, complicated history of Beowulf criticism - the tangled mix of ideologies, national prejudices and wishful thinking that Tolkien $(1958,6)$ calls the "tulgy wood of conjecture". In his notes and delivered lecture, Tolkien seems to have been answering challenges that Grundtvig supplied. Grundtvig was able to elicit from the poem a symbolic account of history. His project was exegetical, but not literary. Tolkien was able to build upon Grundtvig's observations and establish the literary merit of the poem by identifying its patterns and themes which enabled him to formulate his overall judgment, which was indeed original.

I will therefore conclude that, through a process of indirect inheritance and direct engagement, Tolkien gathered the most promising seeds of Grundtvig's thinking on Beowulf and nurtured them to full blossom. His lecture is both an extension of Grundtvig's thinking - Grundtvig updated - and a product of his own mind. The unique insights the two men shared, as Christians who held deep patriotic sentiments and a desire to locate enduring truths in ancient poetry, allowed them special access to the mysterious secrets of Beowulf.

\section{Bibliography}

\section{Abbreviations}

US I-X: Holger Begtrup (ed.) (1904-09), Nik. Fred. Sev. Grundtvigs Udvalgte Skrifter, vol. 1-10, Copenhagen.

\section{Works by Grundtvig}

Grundtvig, N. F. S. (1815), "Et Par Ord om det nys udkomne angelsaxiske Digt", Nyeste Skilderie af Kjøbenhavn 60, cols 945-952; 63, cols 981002; 64, cols 9-15; 65, cols 25-30; 66, cols 45-47.

- (1815), "Nok et Par Ord om Bjovulfs Drape", Nyeste Skilderie af Kjøbenhavn 70, cols 1105-1109; 71, 21-25; 71, 39-45.

- (1817), "Om Bjovulfs Drape eller det af Hr. Etatsraad Thorkelin 1815 udgivne angelsachsiske Digt", Danne-Virke II, 207-289.

- (1820), Bjowulfs Drape. Et Gothisk Helte-Digt fra forrige Aar-Tusinde af Angel-Saxisk paa Danske Riim ved N. F. S. Grundtvig, Copenhagen. 
- (1832), Nordens Mythologi eller Sindbilled-Sprog historisk-poetisk udviklet og oplyst af Nik. Fred. Sev. Grundtvig, Prcest, Copenhagen. US V, 376-768.

- (1831), Bibliotheca Anglo-Saxonica: Prospectus, and Proposals of a Subscription, for the Publication of the Most Valuable Anglo-Saxon Manuscripts, Illustrative of the Early Poetry and Literature of our Language, most of which have never been printed. 1830. London.

- (1861). Beowulfes Beorh eller Bjovulfs-Drapen, det Old-Angelske Heltedigt, paa Grund-Sproget, ved Nik. Fred. Sev. Grundtvig. Copenhagen.

\section{Works by other authors}

Agøy, Nils Ivar (1995), "Quid Hinieldus Cum Christo? New Perspectives on Tolkien's Theological Dilemma and His Sub-Creation Theory" in Patricia Reynolds and Glen H. GoodKnight (eds), Proceedings of the $J$. R. R. Tolkien Centenary Conference, Keble College, Oxford, 1992, Altadena, California, 31-38.

Bradley, S. A. J. (1990), "Grundtvig, Anglo-Saxon Literature, and 'Ordets Kamp til Seier", Grundtvig-Studier 1990, 216-245.

Chambers, R. W. (1925), "Foreword." Beowulf translated into modern English rhyming verse by Archibald Strong. London.

- (1932), On the Continuity of English Prose from Alfred to More and His School, Early English Text Society, London.

Chance, Jane (2001), Tolkien's Art: A Mythology for England, $2^{\text {nd }}$ ed., Lexington.

Clark, George (1990), Beowulf, Boston.

- (1997), "The Hero and the Theme" in Robert E. Bjork and John D. Niles (eds), A Beowulf Handbook, Lincoln: University of Nebraska Press, 271290.

Drout, Michael (2002), Beowulf and the Critics by J. R. R. Tolkien, Tempe, Arizona, Introduction, 1-29.

- (2004), "A Mythology of Anglo-Saxon England" in Jane Chance (ed.), Tolkien and the Invention of Myth: A Reader, Lexington, Kentucky, 229248.

Earl, John (1892), The Deeds of Beowulf, an English Epic of the Eighth Century Done into Modern Prose, Oxford.

Fry, Donald K. (1968), The Beowulf Poet, Englewood Cliffs, New York. Fulk, R. D. (1991), Preface, Interpretations of Beowulf, Bloomington.

Grimm, Jacob (1823), "Kopenhagen. Gedruckt bei Andreas Seidelin. Bjowulfs Drape. Et Gothisk Helte-Digt fra forrige Aar-Tusinde af Angel Saxisk paa Danske Riim ved Nik. Fred. Sev. Grundtvig, Präst. LXXIV und 325 Seiten Octav", Göttingische gelehrte Anzeigen, 1-12; and Kleiner Schriften, vol. 4, Berlin 1869, 178-186.

Haarder, Andreas (1965), "Et gammelt indlæg i en ny debat: Grundtvigs vurdering af Beowulf som kunstværk", Grundtvig-Studier 1965, 7-36.

- (1975). Beowulf. The Appeal of a Poem, Viborg. 
Lerer, Seth (1997), "Contemporary Critical Theory and Beowulf" in Robert E. Bjork and John D. Niles (eds), A Beowulf Handbook, Lincoln, 325339.

Lundgreen-Nielsen, Flemming (1994), "Grundtvig's Norse Mythological Imagery - an Experiment That Failed" in Andrew Wawn (ed.), Northern Antiquity. The Post-Medieval Reception of Edda and Saga, Enfield Lock, Middlesex, 41-67.

Lönnroth, Lars (1988), "The Academy of Odin: Grundtvig's Political Instrumentalization of Old Norse Mythology" in Gerd Wolfgang Weber (ed.), Idee · Gestalt - Geschichte: Festschrift Klaus von See. Odense, 338354.

Malone, Kemp (1940), "Grundtvig's Philosophy of History", Journal of the History of.Ideas 1.3, 281-298, 339-354.

- (1941), "Grundtvig as Beowulf Critic", Review of English Studies 17, 129138.

- (1960), "Grundtvigs oversættelse af Beowulf", Grundtvig-Studier 1960, 7 25.

- (1961), "Symbolism in 'Beowulf': Some Suggestions", English Studies Today, $2^{\text {nd }}$ Series, Bern, 81-91.

Niles, John D (1983), Beowulf: The Poem and Its Tradition, Cambridge, Massachusett.

Patch, Howard R. (1939), Review of "Beowulf: The Monsters and the Critics", Modern Language Notes, 5.3, 217-218.

Shippey, T. A. (1977), "Grimm, Grundtvig, Tolkien: Nationalisms and the Invention of Mythologies" in Maria Kuteeva (ed.), The Ways of Creative Mythologies: Imagined Worlds and their Makers, Telford, 7-17.

- and Andreas Haarder (eds) (1998), Beowulf. The Critical Heritage, London.

- (2003), The Road to Middle-Earth. How J. R. R. Tolkien Created a New Mythology, New York.

- (2004), "Light-elves, Dark-elves, and Others", Tolkien Studies 1.1, 1-15.

Stanley, E. G. (1994), In the Foreground: Beowulf, London.

Tolkien, J. R. R. (1927), "Philology: General Works", The Year's Work in English Studies, London, 33-66.

- and E. V. Gordon (eds) (1936), Songs for the Philologists, London: Privately published.

- (1938), "Letter to the Editor", The Observer, 20 February 1938, 9.

- (1958), Beowulf: The Monsters and the Critics, $2^{\text {nd }}$ ed., Oxford.

- (1981), The Letters of J. R. R. Tolkien, edited by Humphrey Carpenter and Christopher Tolkien, Boston.

- (2002), Beowulf and the Critics, edited by Michael Drout, Tempe, Arizona. 